East African Journal of Science, Technology and Innovation, Vol. 2 (4): September 2021

This article is licensed under a Creative Commons license, Attribution 4.0 International (CC BY 4.0)

\title{
A Goal-Oriented Requirements Engineering Framework for E-government Information Systems
}

\author{
1* NYANSIRO J B., MTEBE J S., KISSAKA M M \\ 1*Department of Computer Science and Engineering, University of Dar es Salaam \\ ${ }^{*}$ Corresponding author: jnyansiro@gmail.com
}

\begin{abstract}
E-government information systems projects in developing countries face several challenges that lead to their partial or total failure. Several causes of e-government information systems project failure have been identified, including inadequate requirement engineering. The overall failure rate of e-government information systems projects due to requirements engineering inadequacies is still high. Inadequate requirement engineering leads to systems with missing features, low quality, project costs, and time overrun. This research aims to design a framework to guide practitioners in e-government information systems requirements engineering processes. The design science research approach and qualitative data collection and analysis methods were applied through three iterative cycles of rigor, design, and relevancy. The proposed framework is based on goals and viewpoints requirements engineering. It consists of three models: the e-government viewpoints model, the e-government goals model, and the e-government requirements engineering process model. The framework was validated through two rounds of Delphi focus group discussion techniques and a single technical action research case study. The results showed a strong consensus among practitioners about the proposed framework's ease of use and utility with a mean agreement of 4.429/5. The technical action research involved five practitioners who applied the proposed framework to discover the requirements of the road emergency response module of road safety information systems of Tanzania. A total of 104 requirements were discovered compared to nine requirements elicited before without using the proposed framework. The overall objective of the proposed framework is to facilitate the discovery and specification of adequate and relevant requirements for e-government information systems projects and ultimately reduce the rate of e-government projects failure and contribute to the realisation of e-government benefits.
\end{abstract}

Keywords: E-government; E-government Framework; Requirements Analysis; Requirements Elicitation; Requirements Engineering

Received: $\quad 23 / 01 / 21$

Accepted: $\quad 15 / 08 / 21$

Published: $\quad 25 / 09 / 21$

Cite as: Nyansiro et al., (2021). A Goal-Oriented Requirements Engineering Framework for Egovernment Information Systems. East African Journal of Science, Technology and Innovation 2(4).

\section{Introduction}

During the last three decades, many governments worldwide have introduced Information and Communication Technologies (ICT) in government operations. These initiatives, collectively known as e-government, aim to improve service delivery and government administrative processes (Sánchez-Torres \& Miles, 2017). In service delivery, e-government 
information systems (IS) have been praised for promoting people-centric services, accountability, effectiveness, and efficiency. Other benefits of egovernment include improved participation, inclusion, transparency, and trustworthiness in public services.

In realizing the importance of e-government in improving service delivery, the Tanzania Information and Communication Technology (ICT) policy released in 2016 emphasizes strengthening the capacity of the institutions responsible for coordinating, providing oversight, regulating, promoting, and enforcement of egovernment and other e-services initiatives. The policy calls for creating a supportive environment for collaboration with various stakeholders in developing e-government in the country.

According to the United Nations, Tanzania falls in the category of middle E-government Development Index - EGDI, which is between 0.25 and 0.50, having EGDI of 0.33533 in 2016, 0.3929 in 2018, and 0.4206 in 2020. The top five countries in Africa under this group are Rwanda with an EGDI of 0.4789 (2020), Lesotho with an EGDI of 0.4593 (2020), Uganda with an EGDI of 0.4499 (2020), Togo with an EGDI of 0.4302 (2020), and Zambia with EGDI of 0.4242 (2020). Denmark, the Republican of Korea, and Estonia are the leading countries in the world with EDGI of $0.98,0.96$, and 0.95, respectively. EGDI assesses egovernment development at a national level based on available online services, telecommunication infrastructure, and ICT human capital on a scale of 0 to 1 (United Nations, 2016, 2018, 2020).

Although there has been promising progress across the continent, the implementation of egovernment (IS) projects in developing countries still face several turbulences that lead to partial or total failure (Choi and Chandler, 2020). As a result, millions of taxpayers' monies are wasted. (Abbas et al., 2017). It is estimated over $40 \%$ of IS project problems are caused by inadequate systems requirements specifications (Anwer et al., 2019). Common RE issues include: lack of user involvements; changing requirements; missing critical requirements; incomplete requirements; ambiguous requirements; poor requirements traceability; elicitation of irrelevant requirements; and poor requirements change management (Boota et al., 2014; Hussain et al., 2016; Shah \& Patel, 2014).

Due to inadequate requirements engineering (RE), in many developing countries, the benefits of egovernment are seen as hypes rather than reality, as citizens do not evidence them in real life to justify the considerable investment (Paulin, 2015). Most e-government systems in developing countries are not citizen-centric (Mukamurenzi et al., 2019). They are designed and developed without crucial features and quality required by citizens in terms of process, service, and information. Unlike other information systems, designing and developing e-government information systems requires a thorough consideration of political, economic, socio-cultural, technological, and legal factors (Joseph \& Avdic, 2016; Mkude \& Wimmer, 2013).

There is still a lack of a comprehensive framework and guidelines to aid and guide the reengineering of e-government IS requirements. Few researchers have attempted to address this problem. For example, Tambouris et al., 2014, developed a set of e-government IS requirements consisting of 186 requirements. The set comprised of functional, security, usability, reliability, performance, supportability, design, and interface requirements. Palkovits \& Wimmer (2003) proposed a model for modelling public e-services. The framework suggests that the business process models for public service should have three sub-models; the administrative service model, the process map, and the organisational model.

This study aims to design a requirements engineering framework for e-government systems to reduce e-government project failure rates and facilitate the realisation of e-government benefits. In addressing this objective, the design science research (DSR) approach coupled with a number of qualitative data collection and analyses were applied. The Government Information System Requirement Engineering Framework (GISREF) is proposed. The framework consists of three models; the E-government Viewpoints Model (EVM), the E-government Goals Model (EGM), and the Egovernment Requirements Engineering Process Model (EREPM). The overall objective of GISREF is to guide the requirements engineers throughout the e-government IS RE process. This study's contributions are twofold; first, the study 
provides a framework that improves analysts' understanding to discover and elicit critical requirements for e-government IS. Second, the study addresses the problem of methodology and technique in eliciting requirements for egovernment IS.

The proposed framework is based on goals and viewpoints-oriented requirements engineering. Viewpoint is the perspective from which a particular thing is considered or assessed. The concept of viewpoints in requirements engineering was first proposed by (Mullery, 1979). Viewpoints describe possible diverse sources of requirements for a system under development. They provide mechanisms for the identification, organisation, and classification of system requirements. Goals play an essential role in the RE process as they provide the foundation for elaborating requirements and criteria for benchmarking the developed system (Abrahão et al., 2019). Therefore, using viewpoints and goals together increases the chances for discovering critical requirements of a system.

\section{Materials and Methods}

The study adopted a design science research (DSR) approach, coupled with qualitative data collection and analysis methods, including systematic literature review, qualitative metasynthesis, Delphi technique for focus group discussion, questionnaire, and technical action research (TAR). The research was organised in six phases of problem identification and motivation, establishing the knowledge base, design and development of the framework, validation, demonstration, and communication as illustrated in Figure 1 (Hevner \& Chatterjee, 2010).

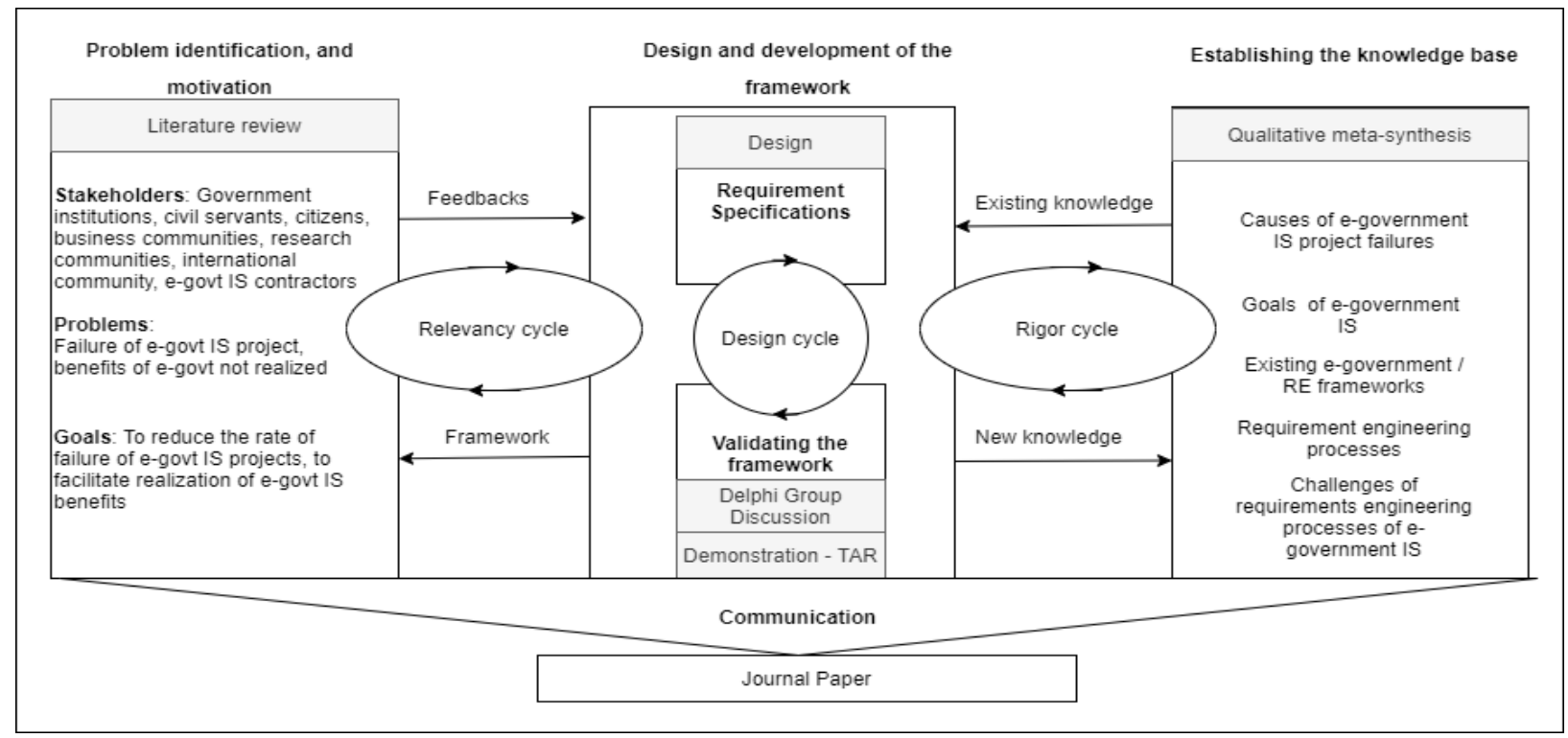

Figure 1. A research framework

\section{Problem identification and motivation}

This phase involves establishing an understanding of the environment, the context, the problem domain, and the anticipation of possible solutions. The environment and context defining the stakeholders, their problems, and their desires are summarized in Figure 1. This phase was achieved through a literature review.

\section{Establishing the knowledge base}

In achieving the objective of this study, it was important to understand the benefits of e- government IS, why e-government IS projects fail, and the challenges facing the RE process of e-government IS. This knowledge was established using qualitative meta-synthesis methodology. The researchers performed several iterations of searching for relevant articles. Popular databases were used, including Google Scholar, Association for Computing Machinery (ACM) Digital Library, Research Gate, the Institute of Electrical and Electronics Engineers (IEEE) Xplore, Springer, Wiley, and ScienceDirect. Various keywords and advanced 
search techniques were performed. A total of 301 articles were obtained; 86 articles for egovernment failure and 128 articles for goals and benefits of e-government. Other articles include 28 articles for the RE process and 59 articles for erequirements engineering frameworks. These articles were reviewed to exclude those which were not relevant. The selected criteria were a journal, conference, and industry articles focusing on one of the following topics; failure and benefits of e-government systems, egovernment development frameworks, and IS requirement engineering. Sixty-four articles for egovernment IS failure, 126 articles for benefits of e-government, 24 articles for the RE process, and 48 articles for requirements engineering passed the selection criteria. Root cause analysis was also applied to understand and establish the root causes of the challenges facing the requirements engineering of e-government IS.

Using an emergent thematic coding approach, data were captured, analysed, and coded. A total of 27 goals of e-government were identified, as shown in Table 1; 18 factors for e-government IS project failure were identified, as shown in Table 2; $16 \mathrm{RE}$ activities summarised in Table 3; 8 challenges and 36 root causes of inadequate egovernment IS requirements engineering processes in Table 4.

\section{Design and development of the framework}

The requirements specifications to guide the design and development, Table 5, were derived from the list of challenges of the e-government $\mathrm{RE}$ process and their root cause, Table 4. In satisfying these requirements specifications, three models were designed. The E-government Goal Model - EGM, Figure 2 was created by rearranging the identified goals in Table 1 into a goal graph. The E-government Viewpoint Model

Table 1. Goals of E-government Information Systems
- EVM was designed by organising similar goals and failure factors presented in Tables 1 and 2 into groups of themes. These themes were later re-named to represent viewpoints as presented in Tables 6 and 7 and Figure 3. The E-government Requirements Engineering Process Model EREPM, Figure 4, was designed from rearranging RE activities shown in Table 3 and practical experience using the EGM and EVM through the technical action research.

\section{Framezork validation}

The proposed framework was validated through practitioners' opinions. A two-round of Delphi focus group validation was conducted. The first round involved 15 e-government practitioners from five ministries, two agencies of the government of Tanzania, and two NonGovernmental Organisations - NGOs working on Tanzania's e-government initiatives. The second round involved seven e-government practitioners gathered from the three ministries and one executive agency from Tanzania. The selection criteria to invite the experts was based on their experience in e-government and that they had ongoing e-government IS projects with their organisations. Members were required to have at least five years of experience in developing e-government systems as recommended (Hallowell \& Gambatese, 2010). The framework was presented to the practitioners, followed by a discussion, comments, questions, and answers. The practitioners were asked to complete a specific questionnaire to rate the framework's ease of use and utility. The questions were designed using a five-point Likert scale to measure the extent of agreement. The scale ranged from strongly disagree (1) to strongly agree (5). Comments and suggestions of the experts summarised in Table 8 were incorporated in the framework design.

\begin{tabular}{cll}
\hline S/N & \multicolumn{1}{c}{ E-government Goals } & \multicolumn{1}{c}{ Literature } \\
\hline $\mathbf{1}$ & To improve effectiveness and & Ayachi et al., (2016), Abu-shanab (2015), Cordella \& \\
& efficiency & Tempini (2015), Damodaran et al., (2005), Elenezi et \\
& & al., (2017), Hanna et al., (2009), Irani et al., (2006), \\
& & Jackson et al., (2015), Juell-Skielse et al., (2017), \\
& & Kassen (2015), Kayed et al., (2010), Komba \& \\
& & Ngulube (2014), Mawela et al., (2017), Mpinganjira \\
\hline
\end{tabular}


(2015), M. R. Zakaria \& Gebba (2014), Owusu-Ansah (2014), Putra et al., (2018), Rana et al., (2015), Sánchez-Torres \& Miles (2017), Stephen et al., (2017), Shrivastava et al., (2014), Stefanovic et al., (2016), Sorn-in et al., (2015), Waldt (2002)

2 To improve transparency

3 To provide improved and convenient services

$4 \quad$ To reduce transaction costs

$5 \quad$ To improve business processes

6 To improve accountability

$7 \quad$ To provide integrated services

8 To improve public administration and management

9 To improve collaboration, cooperation, coordination, and information sharing between government agencies

10 To improve citizen participation

11 To improve accessibility and quality of government information
Abu-shanab (2015), Ayachi et al., (2016), Gupta et al., (2016), Jackson et al., (2015), Kassen (2015), Komba \& Ngulube (2014), Sánchez-Torres \& Miles (2017), Shrivastava et al., (2014), Stephen et al., (2017), Stefanovic et al., (2016), Sun et al., (2015), M. R. Zakaria \& Gebba (2014), Owusu-Ansah (2014), Putra et al., (2018), V. D. Ndou, (2004), Waldt (2002) Australia. National Office for the Information Economy. \& DMR Consulting. (2003), Damodaran et al., (2005), Elenezi et al., 2017), Jacob et al., (2017), Sánchez-Torres \& Miles, (2017), Shrivastava et al., (2014), Stephen et al., (2017), Sun et al., (2015)

Ayachi et al., (2016), Australia. National Office for the Information Economy. \& DMR Consulting. (2003), Gupta et al., (2016), Hanna et al., (2009), Irani et al., (2006), Jackson et al., (2015), Jacob et al., (2017), M. R. Zakaria \& Gebba, (2014), Stephen et al., (2017), Sun et al., (2015), V. D. Ndou (2017), Waldt (2002), Damodaran et al., (2005), Irani et al., (2006), Jackson et al., (2015), Sánchez-Torres \& Miles (2017)

Abu-shanab (2015), Gupta et al., (2016), Hanna et al., (2009), Irani et al., (2006), Jackson et al., (2015), Kassen (2015), Owusu-Ansah (2014), Rana et al., (2015), Sánchez-Torres \& Miles (2017), Stephen et al., (2017), V. D. Ndou (2004), Waldt (2002)

Elenezi et al., (2017), Jackson et al., (2015), JuellSkielse et al., (2017), Putra et al., (2018), Reffat (2003), Sorn-in et al., (2015), Shrivastava et al., (2014), Stefanovic et al., (2016), Sun et al., (2015), Waldt (2002)

Abu-shanab (2015), Chutimaskul et al., (2008), Irani et al., (2006), Kassen (2015), Mawela et al., (2017), Sánchez-Torres \& Miles (2017), Stephen et al., (2017), Vrakas et al., (2010),

Damodaran et al., (2005), Elenezi et al., (2017), Irani et al., (2006), Juell-Skielse et al., (2017), M. R. Zakaria \& Gebba (2014), Putra et al., (2018), Sun et al., (2015), Waldt (2002)

Abu-shanab (2015), Kayed et al., (2010), , Mpinganjira (2015), M. R. Zakaria \& Gebba (2014), Reffat (2003), Owusu-Ansah (2014), Shrivastava et al., (2014) , Sun et al., (2015)

Elenezi et al., (2017), Jackson et al., (2015), Kassen (2015), Mpinganjira (2015), M. R. Zakaria \& Gebba (2014), Shrivastava et al., (2014) 


\section{To improve democracy}

13 To build trust in citizens

14 To improve decision making

15 To provide reliable service (24/7)

16 To prevent or reduce corruption

17 To increased government capacity to deliver services

18 To facilitate effective policy implementation

19 To improve the business environment

20 To facilitate inclusion of the marginalized

21 To facilitate effective programmes implementation and management

22 To improved social welfare

23 To eliminate bureaucracy

24 To control fraud and embezzlement

25 To provide innovative services

26 To provide personalized and variety of choices of services

27 To reduce paperwork
Abu-shanab (2015), Damodaran et al., (2005), Kassen (2015), Kayed et al., (2010), Mpinganjira (2015), M. R. Zakaria \& Gebba, (2014), Mawela et al., (2017) Jackson et al., (2015), Jacob et al., (2017), Mawela et al., (2017), Owusu-Ansah (2014), Putra et al., (2018), Reffat 92003) ,Stefanovic et al., (2016)

Abu-shanab (2015), Owusu-Ansah (2014), V. D. Ndou (2004),

Gupta et al., (2016), Jacob et al., (2017), Stefanovic et al., (2016), Sorn-in et al., (2015), Vrakas et al., (2010), Waldt (2002),

Jackson et al., (2015), Putra et al., (2018), Sun et al., (2015), V. D. Ndou (2017), Waldt (2002)

(Sorn-in et al., (2015), V. D. Ndou (2004),

Cordella \& Tempini (2015)

Kassen (2015), Hanna et al., (2009), Waldt, (2002), Reffat (2003)

Abu-shanab (2015), Damodaran et al., (2005), Hanna et al., (2009), Jackson et al., (2015), ,

Cordella \& Tempini (2015)

Australia. National Office for the Information Economy. \& DMR Consulting. (2003)

Jackson et al., (2015), Waldt (2002), M. R. Zakaria \& Gebba (2014)

Ayachi et al (2016)

Irani et al., (2006), Kassen (2015), Sánchez-Torres \& Miles (2017)

Damodaran et al., (2005), Sánchez-Torres \& Miles (2017), Waldt (2002),

Shrivastava et al., (2014), Stefanovic et al., (2016), Waldt (2002)

Table 2. Causes of E-government IS Projects Failure

\begin{tabular}{|c|c|c|}
\hline & Causal factor & Literature \\
\hline 1 & $\begin{array}{l}\text { Inadequate system } \\
\text { requirements } \\
\text { engineering }\end{array}$ & $\begin{array}{l}\text { Baguma and Lubega (2013), Goedeke et al., (2017), Hussain et al., } \\
\text { (2016), Sweis (2015), Hofmann and Lehner (2001), Bubenko (1995), } \\
\text { Michael and Boniface (2014), Zakaria et al., (2011) }\end{array}$ \\
\hline 2 & $\begin{array}{l}\text { Inadequate project } \\
\text { management }\end{array}$ & $\begin{array}{l}\text { Afyonluoğlu et al., (2014), Aikins (2012), Baguma and Lubega } \\
\text { (2013), Goedeke et al., (2017), Gunawong and Gao (2017), Hossan } \\
\text { et al., (2006), Imran et al., (2017), Rajapakse et al., (2012),(Rajala and } \\
\text { Aaltonen (2020), Sweis (2015), S. R. A. Shah et al., (2011), } \\
\text { Twizeyimana et al., (2018) }\end{array}$ \\
\hline 3 & $\begin{array}{l}\text { Missing or incomplete } \\
\text { features }\end{array}$ & $\begin{array}{l}\text { Baguma and Lubega (2013), Damoah and Akwei (2017), (Goedeke } \\
\text { et al., (2017), Gunawong and Gao (2017) }\end{array}$ \\
\hline 4 & $\begin{array}{l}\text { Inadequate project } \\
\text { planning }\end{array}$ & $\begin{array}{l}\text { Aikins (2012), Baguma and Lubega (2013), Bakunzibake et al., } \\
\text { (2018), Ghapanchi and Albadvi (2008), Goedeke et al., (2017), }\end{array}$ \\
\hline
\end{tabular}


Hossan et al., (2006), Rajala and Aaltonen (2020), Rajapakse et al., (2012), (Twizeyimana et al., (2018)

5 Inappropriate choice of technology

6 Insufficient top management support

$7 \quad$ Integration failure

8 Procurement and contract shortcomings

9 Inadequate business process management $(\mathrm{BPM})$

10 Insufficient IS testing

11 Insufficient change management

12 Staffing and skills shortfalls

13 Technical overcomplexity

14 Obsolete technology

15 Information gaps

16 Inadequate infrastructure

17 Political interference

18 Inappropriate organisational management structure
Goedeke et al., (2017), Ghapanchi and Albadvi (2008), Lau (2003)

Aikins (2012), Baguma and Lubega (2013), Bakunzibake et al., (2018), Goedeke et al., (2017), Ojha and Pandey (2017), Sweis (2015), ,

Al-khanjari et al., (2014), Ghapanchi \& Albadvi (2008), Goedeke et al., (2017), Lam (2005)

Goedeke et al., (2017), Ojha and Pandey (2017), Rajapakse et al., (2012)

Afyonluoğlu et al., (2014), Baguma and Lubega (2013), Bakunzibake et al., (2018), Dada (2006), Goedeke et al., (2017), Gartlan \& Shanks (2007), Martin and Montagna (2006), Reffat (2003), (Swartz (2018), Trkman (2010)

Goedeke et al., (2017), Mansor and Ndudi (2015), Rajala and Aaltonen (2020), (Rajapakse et al., (2012)

Afyonluoğlu et al., (2014), Aikins (2012), (Bakunzibake et al., (2018), Ghapanchi and Albadvi (2008), Dada (2006), Hossan et al., (2006), (Nograsek (2011)

Abbas et al., (2017), Baguma and Lubega (2013), Dada (2006), Goedeke et al., (2017), Hossan et al., (2006), Rajala and Aaltonen (2020), Rajapakse et al., (2012), Ojha and Pandey (2017), Twizeyimana et al., (2018), Zakaria et al., (2011)

Goedeke et al., (2017), Abbas et al., (2017), Botchkarev and Finnigan (2015), Sweis (2015), Lau ( 2003), Mukherjee (2008)

Baguma and Lubega (2013), Goedeke et al., (2017)

Heeks (2001), Rajapakse et al., (2012), Vyas et al., (2014)

Baguma and Lubega (2013), Dahiya and Mathew (2018), Bakunzibake et al., (2018), Goedeke et al., (2017), Hossan et al., (2006), Rahman et al., (2014), Twizeyimana et al., (2018)

Abbas et al., (2017), Baguma and Lubega (2013), Hossan et al., (2006), Rajala and Aaltonen (2020), Toots (2019)

Abbas et al., (2017), Goedeke et al., (2017), Rajala and Aaltonen (2020), S. R. A. Shah et al., (2011)

Table 3. Activities in RE Process

\begin{tabular}{ll}
\hline S/N & Activities \\
\hline 1 & Requirements elicitation/gathering \\
2 & Requirements documentation \\
3 & Requirements analysis \\
4 & Requirements validation \\
5 & Requirements negotiation \\
6 & Requirements verification \\
7 & Requirements modelling \\
\hline
\end{tabular}




\begin{tabular}{cl}
\hline $\mathbf{8}$ & Requirements management \\
9 & Data analysis \\
10 & Behavioural analysis \\
11 & Functional analysis \\
12 & Requirements specification \\
13 & Problem analysis \\
14 & Feasibility study \\
15 & Structural analysis \\
16 & Architectural analysis \\
\hline
\end{tabular}

\section{Framework demonstration}

The proposed framework was tested using a realworld problem through single technical action research. A team of five officials from institutions responsible for road safety and emergency services in Tanzania applied the framework to discover the requirements of the road emergency response module (RER) of the road safety information system. The team was comprised of two IT officers, one police officer, one emergency medical officer, and one road safety engineer. This system was planned to be implemented by the Tanzania National Roads Agency TANROADS and Muhimbili National Hospital $\mathrm{MNH}$. The main objectives of this system were to establish an emergency call centre and an ambulance dispatch centre. Nine high-level requirements were established before the use of the proposed framework.

Table 4. Challenges of E-government IS Requirements Engineering Processes

\begin{tabular}{|c|c|c|c|}
\hline $\mathrm{S} / \mathrm{N}$ & Challenge & Root Causes & Reference \\
\hline 1 & $\begin{array}{l}\text { The challenge of } \\
\text { understanding }\end{array}$ & $\begin{array}{l}\text { Unclear project objectives and } \\
\text { goals among stakeholders } \\
\text { A vague understanding of needs } \\
\text { among stakeholders. } \\
\text { Inadequate or no feasibility study } \\
\text { is conducted } \\
\text { Inadequate user involvement - } \\
\text { prospective users (citizens) not } \\
\text { involved } \\
\text { Limited understanding of } \\
\text { technology capabilities and } \\
\text { limitations among systems and } \\
\text { business analysts } \\
\text { Limited understanding of } \\
\text { business processes (domain } \\
\text { knowledge) among systems } \\
\text { analysts. } \\
\text { Limited understanding of RE } \\
\text { knowledge among systems and } \\
\text { business analysts. } \\
\text { Limitations of natural languages/ } \\
\text { communication difficulties. } \\
\text { Inconsistency and terminology } \\
\text { conflicts. }\end{array}$ & $\begin{array}{l}\text { Baguma and Lubega (2013), } \\
\text { Bubenko (1995), Brewer et al., } \\
\text { (2006),Goedeke et al., (2017), } \\
\text { Hussain et al., (2016), Simonofski } \\
\text { et al., (2018), Sweis (2015), } \\
\text { Hofmann and Lehner (2001), } \\
\text { Michael and Boniface (2014), } \\
\text { Zakaria et al., (2011), van Velsen } \\
\text { et al., (2009) }\end{array}$ \\
\hline
\end{tabular}


2 The challenge of volatility

3 The challenge of resources (staff, time, and financial)

4 The challenge of standards, methodology, and techniques

5

The challenge of tools

6

Limited prospective users involvement
Business process flows and use-

cases not captured for all user

groups and scenarios

The top management team are not

aware of the importance of RE

Differing perspective among

stakeholders

Lack of formal changes

management procedures.

Frequent change of policies acts, and administrative structures

Poor information capturing and

management during the RE

process

Changes in project scope

Insufficient financial resources

Insufficient human resources

Inadequate RE skills among RE

team

Political pressures to complete the

project within a short time

Limited professional

specialization within units or

department responsible for e-

government.

RE standards, methodologies, and techniques not known

RE standards, methodologies, and techniques not correctly applied

Business rules are not captured

correctly.

Incomplete or inadequate documentation of requirements

Lack or inadequate RE tools

Inadequate fund to purchase the

necessary tool

Tools not known

Lack of effective tools

Lack of sufficient methodology to involve users, especially citizens, because of their diversity.

Availability of a diverse number of users with varying characteristics (heterogeneous user groups).

Multiple operating scenarios and environments
Bubenko (1995), Goedeke et al., (2017), Hussain et al., (2016), Simonofski et al., (2018), Sweis (2015), Hofmann and Lehner (2001), Michael and Boniface (2014), Zakaria et al., (2011)

Baguma and Lubega (2013), Bubenko (1995), Goedeke et al., (2017), Hussain et al., (2016), Simonofski et al., (2018), Sweis (2015), Hofmann and Lehner (2001), Michael and Boniface (2014), Zakaria et al., (2011), van Velsen et al., (2009)

Goedeke et al., (2017), Hussain et al., (2016), Sweis (2015), Hofmann and Lehner (2001), Bubenko (1995), Michael and Boniface (2014), Zakaria et al., (2011)

Goedeke et al., (2017), Sweis (2015), Hofmann and Lehner (2001), Bubenko (1995), Michael and Boniface (2014), Zakaria et al., (2011)

Baguma and Lubega (2013), Bubenko (1995), Goedeke et al., (2017), Hussain et al., (2016), Simonofski et al., (2018), Sweis (2015), Hofmann and Lehner (2001), Michael and Boniface (2014), Zakaria et al., (2011), van Velsen et al., (2009)

Baguma and Lubega (2013), Bubenko (1995), Goedeke et al., (2017), Hussain et al., (2016), Simonofski et al., (2018), Sweis (2015), Hofmann and Lehner (2001), Michael and Boniface 


\begin{tabular}{|c|c|c|c|}
\hline & & $\begin{array}{l}\text { Multiple stakeholders and } \\
\text { integration partners } \\
\text { Lack of clear guideline / } \\
\text { documentation to enable the } \\
\text { development of interoperable e- } \\
\text { government systems } \\
\text { The complexity of some } \\
\text { government domains }\end{array}$ & $\begin{array}{l}\text { (2014), Zakaria et al., (2011), van } \\
\text { Velsen et al., (2009) }\end{array}$ \\
\hline 8 & $\begin{array}{l}\text { The challenge of legal } \\
\text { frameworks }\end{array}$ & $\begin{array}{l}\text { Availability of multiple laws, } \\
\text { regulations, and guidelines } \\
\text { supporting business operations }\end{array}$ & $\begin{array}{l}\text { Baguma and Lubega (2013), } \\
\text { Bubenko (1995), Goedeke et al., } \\
\text { (2017), Hussain et al., (2016), } \\
\text { Simonofski et al., (2018), Sweis } \\
\text { (2015), Hofmann and Lehner } \\
\text { (2001), Michael and Boniface } \\
\text { (2014), Zakaria et al., (2011), van } \\
\text { Velsen et al., (2009) }\end{array}$ \\
\hline
\end{tabular}

Table 5. Requirements specifications for the design of the framework

\begin{tabular}{|c|c|c|}
\hline $\mathrm{S} / \mathrm{N}$ & Challenge & $\begin{array}{l}\text { Requirements Specification for the Design of the } \\
\text { Framework }\end{array}$ \\
\hline 1 & The challenge of understanding & $\begin{array}{l}\text { 1. The framework should facilitate the discovery and } \\
\text { elaboration of e-government IS objectives and align } \\
\text { them to both sector strategies and the IS to be } \\
\text { developed. } \\
\text { 2. The framework should facilitate the discovery, analysis, } \\
\text { and resolution of requirements for each identified } \\
\text { objective from multiple ideas, perspectives and } \\
\text { stakeholders. } \\
\text { 3. The framework should facilitate capturing and analysis } \\
\text { of business processes and business rules for each } \\
\text { scenario and use case. }\end{array}$ \\
\hline 2 & $\begin{array}{l}\text { The challenge of standards, } \\
\text { methodology, and techniques }\end{array}$ & $\begin{array}{l}\text { 4. The framework should provide a simple step-by-step } \\
\text { method for the e-government IS requirement } \\
\text { engineering process. }\end{array}$ \\
\hline
\end{tabular}




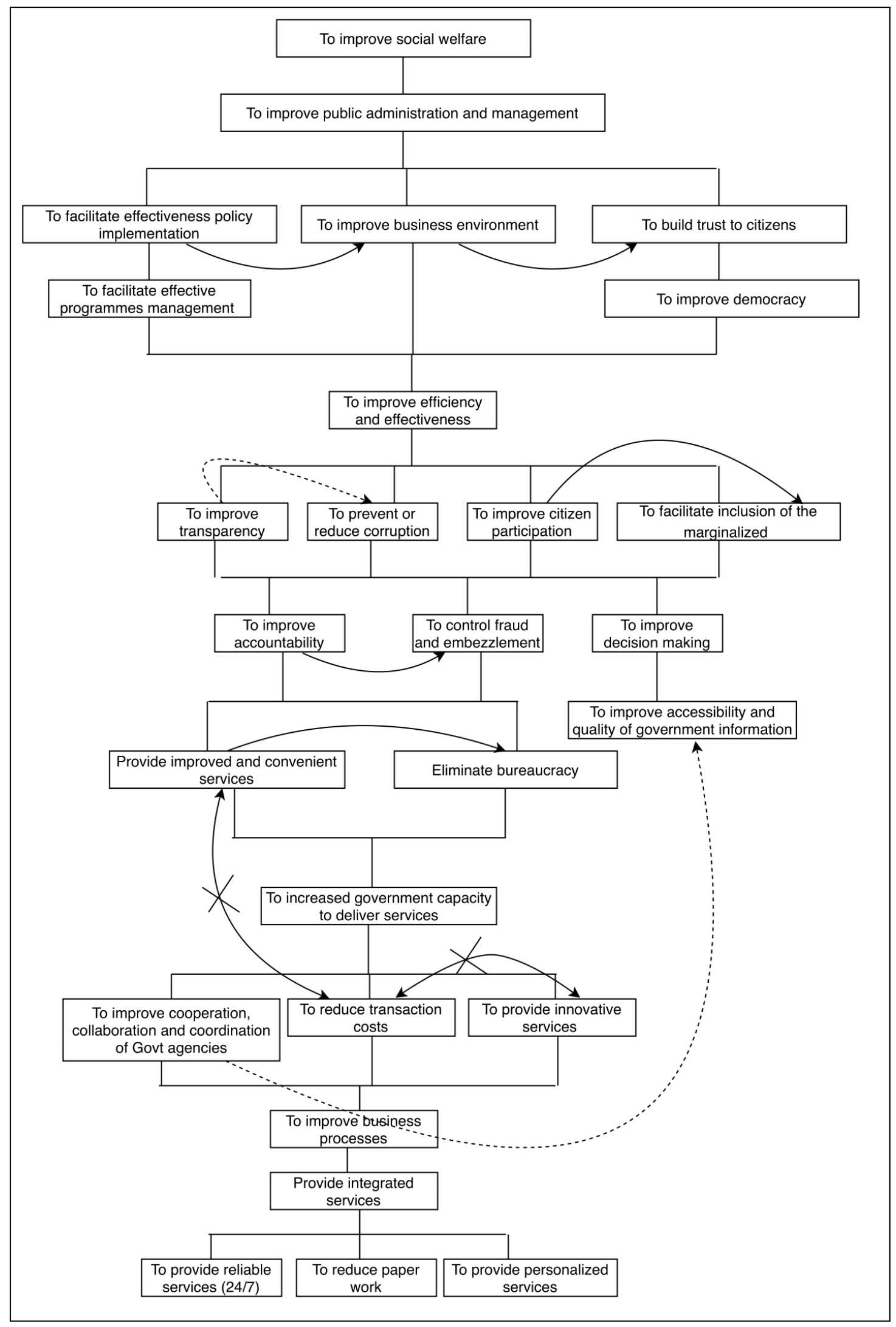

Figure 2. E-government Goals Model (EGM) 


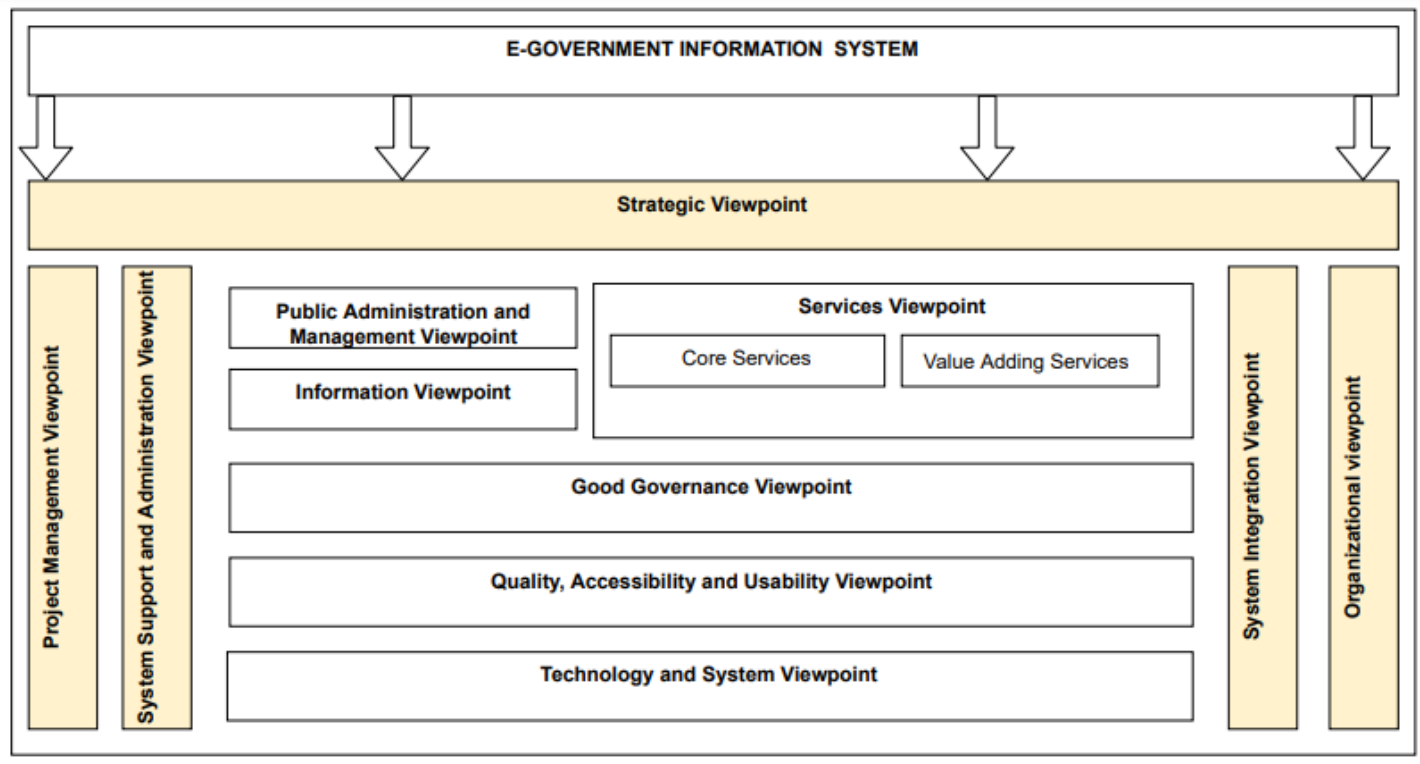

Figure 3. E-government Viewpoints Model

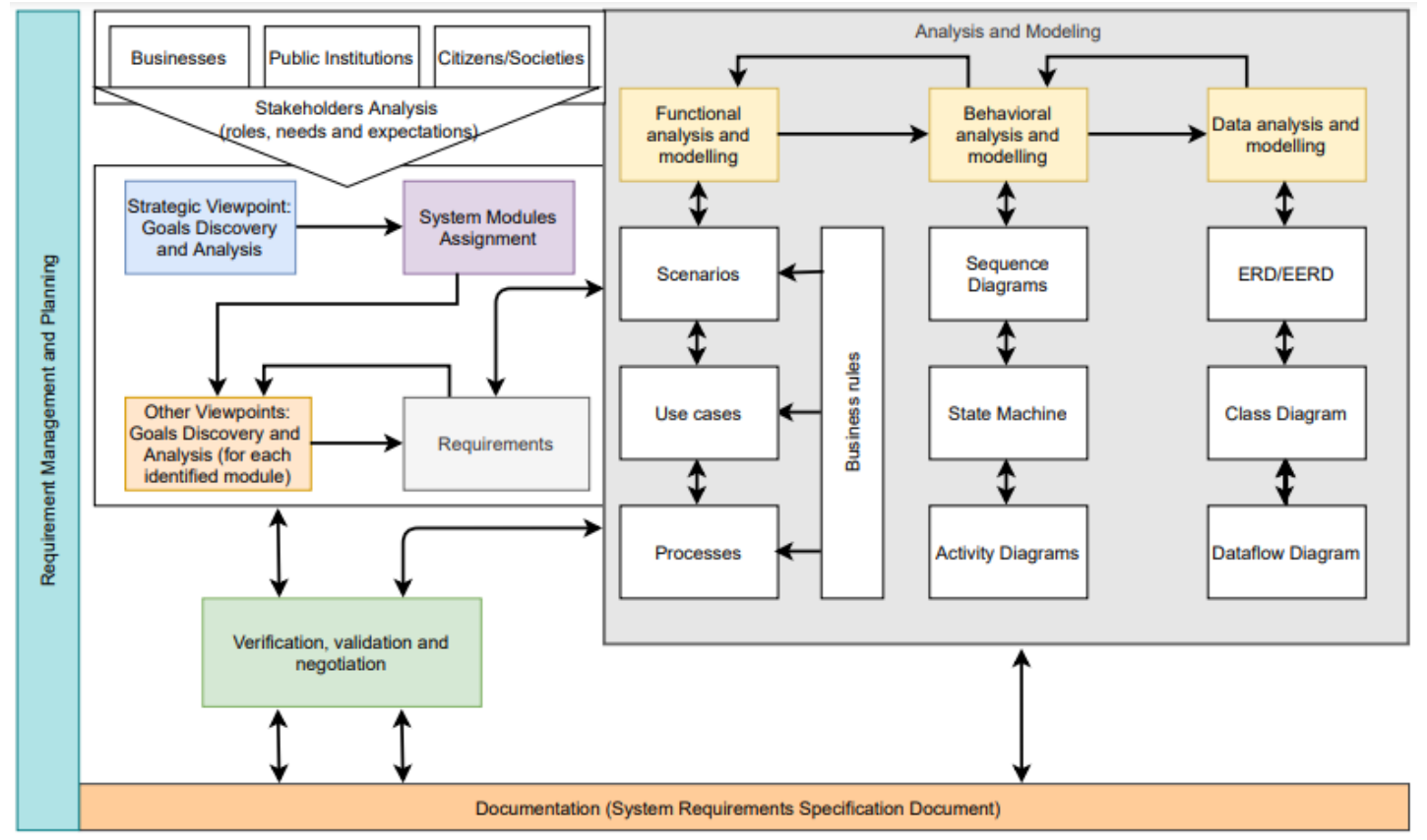

Figure 4. E-government Requirements Engineering Process Model (EREPM) 


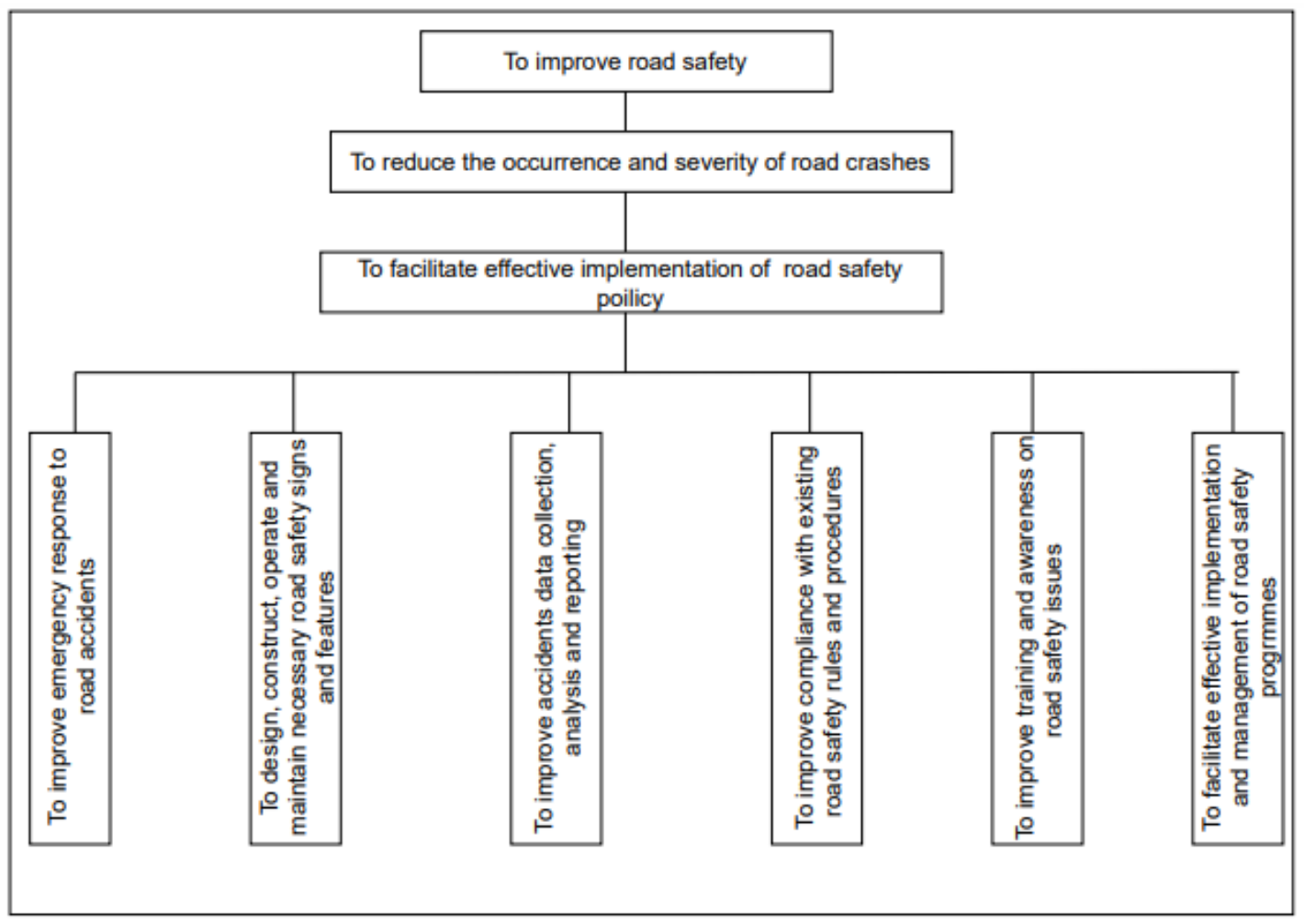

Figure 5. Strategic goal model for road safety information system

Table 6. E-government Viewpoints from Goals Perspective

\begin{tabular}{lll}
\hline $\mathbf{S} / \mathbf{N}$ & \multicolumn{1}{c}{ Goals } & \multicolumn{1}{c}{ Viewpoint Name } \\
\hline 1 & $\begin{array}{l}\text { 1. To improve public administration and management } \\
\text { 2. To facilitate effective policy implementation } \\
\text { 3. To facilitate effective program implementation and } \\
\text { management }\end{array}$ & $\begin{array}{l}\text { Public administration and } \\
\text { management }\end{array}$ \\
& $\begin{array}{l}\text { 4. To improve efficiency and effective } \\
\text { 1. To improve accessibility and quality of government } \\
\text { information }\end{array}$ & Information \\
& & \\
3 & 1. To eliminate bureaucracy & \\
2. To improve business processes & \\
3. To reduce transaction costs & \\
4. To reduce paperwork & Value-add services \\
4 & $\begin{array}{l}\text { 1. To provide personalized services } \\
\text { 2. To provide innovative services }\end{array}$ & \\
1. To prevent corruption & Good governance \\
2. To improve democracy & \\
3. To improve accountability & \\
4. To improve transparency & \\
5. To improve citizen participation &
\end{tabular}


7. To control fraud and embezzlement

8. To improve decision making

9. To build trust in citizens

6 1. To provide reliable services $(24 / 7)$

2. To provide improved and convenient services

Quality, accessibility, and usability System Support and Administration

7 1. To improve cooperation, collaboration, and System integration coordination of government agencies

2. To provide integrated services

Table 7. Viewpoints from E-government IS failure Causes Perspective

\begin{tabular}{|c|c|c|}
\hline S/N & Causal Factors & Viewpoint Name \\
\hline 1 & 1. Poorly or inadequate projects planning & Strategic \\
\hline 2 & $\begin{array}{l}\text { 1. Inadequate project management } \\
\text { 2. Insufficient testing } \\
\text { 3. Inadequate system requirements } \\
\text { engineering } \\
\text { 4. Lack of top management support } \\
\text { 5. Missing or incomplete features } \\
\text { 6. Procurement and contractual issues } \\
\text { 7. Political interference }\end{array}$ & Project management \\
\hline 3 & $\begin{array}{l}\text { 1. Inadequate business process management } \\
\text { (BPM). } \\
\text { 2. Lack of or insufficient change management. } \\
\text { 3. Inadequate organisation management } \\
\text { structure } \\
\text { 4. Shortage of staff and lack of or inadequate } \\
\text { skills } \\
\text { 5. Information gaps }\end{array}$ & Organisational \\
\hline 4 & $\begin{array}{l}\text { 1. Integration failure } \\
\text { 2. Obsolete technology } \\
\text { 3. Inappropriate choice of technology } \\
\text { 4. Inadequate infrastructure } \\
\text { 5. Technical complexities and problems }\end{array}$ & Technology and systems \\
\hline
\end{tabular}

Table 8. A summary of main areas received comments and suggestions from practitioner

\begin{tabular}{lll}
\hline S/N & Main Area & $\begin{array}{l}\text { The number of participants } \\
\text { mentioned }\end{array}$ \\
\hline 1 & Organisational change management & 6 \\
2 & System integration & 4 \\
3 & Project implementation risks & 3 \\
4 & $\begin{array}{l}\text { Relationship between viewpoints } \\
\text { Application of the framework in the agile } \\
\text { environment }\end{array}$ \\
\hline
\end{tabular}




\section{Results}

The purpose of the research was to develop a RE framework of the e-government IS project that could reduce e-government IS projects' failure and facilitate the realisation of e-government benefits. The Government Information System Requirements Engineering Framework is proposed. The framework consists of three models, the E-government Goal Model, the Egovernment Viewpoint Model, and the Egovernment Requirement Engineering Process Model.

\section{The E-government Goal Model}

The E-government Goal Model - EGM presented in Figure 2 is intended to be used by egovernment IS requirements engineers as a reference model for eliciting goals for specific egovernment IS. Elaborating these goals into sector-specific systems will yield several hard and soft goals to be fulfilled by the envisaged IS. The model consists of twenty-seven (27) generic goals to be fulfilled by any particular egovernment IS.

\section{E-government Viewpoints Model}

The E-government Viewpoint Model - EVM presented in Figure 3, consists of twelve (12) egovernment IS viewpoints: four (4) viewpoints from e-government IS project failure perspective; strategic, project management, organisational, technology, and systems viewpoints; and eight (8) viewpoints from e-government IS goals perspective; public administration and management, core services, value-adding services, information, good governance, system integration, quality, accessibility and usability, and system support and administration viewpoints. This conceptual model is intended to be used by requirements engineers of egovernment IS as a reference model to enable them to partition the e-government IS in multiple perspectives during RE. Additional viewpoints and sub viewpoints in specific problem domains can also be established. The twelve viewpoints are described in the coming subsections.

\section{Strategic}

In this viewpoint, the e-government IS project objectives, goals, and values are identified and analysed. Corresponding requirements are also established. While the system may not directly implement goals and requirements in this viewpoint, they mainly serve three purposes: first, they provide benchmarking criteria for evaluating the system; second, they provide means for identifying IS modules; lastly, they help in the identification and elaboration of goals and requirements in other viewpoints.

\section{Public administration and management}

In this viewpoint, goals, and requirements to be considered are those related to improved public administration and management, effective policy implementation, improved efficiency and effectiveness, and effective programmes management. Other elements to consider in this viewpoint include; performance management, managing by results, value for money, effective resources utilization, effective planning, elimination of bureaucracy, customer-focused, etc. (Lufunyo, 2014).

Services

In this viewpoint, services to be offered to different stakeholders are identified. Corresponding goals and requirements are elicited and analysed. The goals in viewpoints include those related to the provision of improved and convenient services, improved business processes, reduction of operation costs, elimination or minimization of bureaucracy, provision of integrated services, personalized services, and reduction of paperwork. The service viewpoint has two sub-viewpoints; core services and value-adding services. Core services correspond to the fundamental services of the government institution implementing the egovernment system. On the other hand, the value-adding services correspond to supplementary services that can be offered to take advantage of the new technology and add value to both stakeholders and the institution. Value-adding services correspond to the goal of offering innovative services. 


\section{Information}

This viewpoint is concerned with the egovernment IS requirements to facilitate improved access and quality of government information in terms of accuracy, timeliness, relevance, precision, and completeness (Oliveira \& Eler, 2017). It is also concerned with analysing information to be capture from users to facilitate government operations, service provision, and decision making.

\section{Good governance}

This viewpoint is concerned with engineering egovernment IS for good governance. The main question that requirements engineers should ask is how the system in question will improve; accountability, transparency, citizen participation, the inclusion of disadvantaged groups, the rule of law, decision making, and other good governance aspects.

\section{Quality, accessibility, and usability}

This is a cross-cutting viewpoint. It is concerned with the quality, accessibility, and usability requirements of e-government systems, commonly known as non-functional requirements.

\section{Technology and system}

This viewpoint is about establishing requirements for the core technologies to be used to implement the e-government system. It includes requirements for e-government infrastructure related to hardware platforms, software platforms, and connectivity technologies.

\section{System integration}

Government institutions do no operate in isolation. They rely upon one another either vertically or horizontally. In this viewpoint, goals and requirements should be elicited to improve cooperation, collaboration, coordination of government agencies, and provision of integrated services.

\section{Organizational}

This viewpoint focuses on organisational requirements for the successful implementation and adoption of the proposed system. The RE team must identify all changes and improvements required by the organisation regarding structure, business processes, staff requirements, job profiles, etc. While this viewpoint's goals and requirements may not be used directly to implement the system, they are essentially useful in developing the organisational changes management plan.

\section{System support and administration}

In this viewpoint, goals and requirements for supporting and administering the system are discovered to ensure adequate users support and administration of the system.

\section{Project management}

In this viewpoint, the RE team should identify project management requirements, including project management activities, system development methodology, schedules, milestones, project management tools, people, and their responsibilities, risks, mitigation measures, and resource requirements for the upcoming phases. The goals are requirements from this viewpoint may not be directly implemented in the system; however, they are helpful in making the project successful.

\section{E-government Requirements Engineering Process Model}

In fulfilling requirements 3 and 4 of the framework requirements specification shown in Table 5, the EREPM presented in Figure 4 was designed. The objective of this model is to guide requirement engineers throughout the $R E$ process of the e-government IS. It elaborates how the EGM and EVM are applied in the RE process. The process is narrated in the below subsections.

\section{Stakeholders Analysis}

The first step in the RE process of the egovernment system is to perform stakeholder's analysis. E-government IS tending to have several stakeholders with varying needs and operating environments. For the successful egovernment IS project needs of each stakeholder must be satisfied by the system. Therefore, the needs and operational characteristics of each stakeholder should be considered throughout the RE process.

\section{Strategic viewpoint analysis}

Strategic goals are discovered and analysed. The strategic goals can be found in the feasibility 
study, policy documents, strategic documents, and other reports. The leaf goals of the strategic goal graph model are assigned to modules to identify information system modules required to fulfill the strategic goals of the sector or institution developing the e-government IS.

\section{Other viewpoints analysis}

Once the e-government IS modules have been identified, each identified module is analysed separately in each viewpoint. Goals are discovered, analysed, and translated into user requirements.

\section{Requirements Analysis}

User requirements are further analysed in terms of functionality, behaviour, and data requirements to establish system requirements specification (SRS). Several methods and techniques for analysing and modelling system context, processes, data, behaviour, and structure have been proposed, such as scenarios, use cases, process, sequence diagrams, activity diagrams, and entity-relationships diagrams.

\section{Framework Validation Results}

The results are summarised in Table 9, indicate a strong agreement consensus among practitioners about the ease of use and utility of GISREF with a mean agreement of 4.429 equivalent to $88.6 \%$, which is above the minimum percentage of agreement which was taken to be $75 \%$, equivalent to 3.750 points. Practitioners suggested two viewpoints, system integration, and system support and administration, to be added to the EVM. There were different views on the application of the framework in an agile environment. However, it was agreed that the requirements from different viewpoints could be discovered at different times, making the framework applicable in an agile environment.

Table 9. Validation questionnaire results

\begin{tabular}{|c|c|c|c|c|c|c|c|c|}
\hline \multirow{2}{*}{ Questions } & \multicolumn{8}{|c|}{ Experts } \\
\hline & A & B & C & D & E & $\mathbf{F}$ & G & MEAN \\
\hline A: Ease of use & 4 & 5 & 4 & 4 & 5 & 4 & 4 & 4.286 \\
\hline $\begin{array}{l}\text { 1. The framework is easy to learn } \\
\text { and understand }\end{array}$ & & & & & & & & \\
\hline 2. The framework is easy to use & 3 & 4 & 4 & 4 & 5 & 4 & 4 & 4.000 \\
\hline $\begin{array}{l}\text { 3. The use of the framework can } \\
\text { yield more e-government IS } \\
\text { requirements }\end{array}$ & 5 & 5 & 5 & 4 & 5 & 5 & 5 & 4.857 \\
\hline \multicolumn{9}{|l|}{ B: Adequacy and Utility } \\
\hline $\begin{array}{l}\text { 4. The framework stimulates } \\
\text { thinking and imaginations of } \\
\text { requirement engineers }\end{array}$ & 5 & 4 & 4 & 4 & 5 & 5 & 4 & 4.429 \\
\hline $\begin{array}{l}\text { 5. If applied, the framework can } \\
\text { help to reduce the rate of e- } \\
\text { government IS failure }\end{array}$ & 5 & 5 & 5 & 4 & 5 & 5 & 5 & 4.857 \\
\hline $\begin{array}{l}\text { 6. If applied adequately, the } \\
\text { framework can help to } \\
\text { facilitate the development of } \\
\text { citizen-centric e-government } \\
\text { IS }\end{array}$ & 4 & 5 & 4 & 4 & 4 & 4 & 4 & 4.142 \\
\hline $\begin{array}{l}\text { 7. If applied, the framework can } \\
\text { facilitate the realisation of the } \\
\text { benefits of e-government }\end{array}$ & 5 & 4 & 4 & 4 & 5 & 5 & 4 & 4.429 \\
\hline
\end{tabular}




\section{Technical Action Research}

The technical action research involved five practitioners who applied the proposed framework to discover the requirements of the road emergency response (RER) module of road safety information systems (RSIS) of Tanzania. A total of 104 requirements were discovered, with 14 requirements in the core services viewpoint compared to nine requirements elicited before without using the proposed framework. None of the requirements in other viewpoints was elicited before. The distribution of the requirements in various viewpoints is shown in Table 10. These results demonstrate the capability of the proposed framework in assisting requirements engineers in discovering more requirements. Therefore, if properly applied, the framework has the potential to minimize the rate of failure of e-government IS project failure and facilitate the realisation of e-government IS benefits.

Table 10. Number of requirements identified for the road emergency response system

\begin{tabular}{lll}
\hline S/N & Viewpoint & Number of Requirements \\
\hline 1 & Organisational & 10 \\
2 & Public administration and management & 15 \\
3 & Information & 5 \\
4 & Core services & 14 \\
5 & Value-adding services & 6 \\
6 & Good governance & 19 \\
7 & Quality, accessibility, and usability viewpoint & 14 \\
8 & Technologies and system viewpoint & 2 \\
9 & System integration viewpoint & 5 \\
10 & System support and administration viewpoint & 7 \\
11 & Project Management & 7 \\
\hline
\end{tabular}

\section{Discussion}

Despite that RE is an old field of study and has been researched a lot in literature, very few frameworks for RE of e-government IS exist. This may be because e-government is a relatively new topic that emerged and has gained popularity in the last two decades. The limited literature on the e-government RE framework implies that requirements engineering in the public sector is an area of study that has not been prioritized. It also suggests that RE processes in e-government IS projects are currently conducted haphazardly without adequate guidance, contributing to the high number of e-government IS project failures.

For example, the road emergency response system proposed by TANROADS aimed to establish emergency medical services call centre and an ambulance dispatcher centre at the Muhimbili National Hospital (MNH). Initially, the system had nine high-level user requirements only. However, with the aid of the proposed framework, 104 high-level requirements were discovered in all twelve viewpoints. The additional requirements found through the use of the framework include those aimed to improve coordination among responsible agencies, monitor the performance of staff, supporting institutional structure and changes required for the system to work, and citizen participation. Other additional requirements discovered include those aimed at providing convenient services through integration with other available systems and providing quality and timely information to the public. All these critical requirements were left out in the initial RE phase.

Traditional RE frameworks and models have several limitations in ensuring a satisfactory RE process, especially in the public sector. Several generic RE frameworks, such as that proposed by Pandey et al., 2010, exist. These frameworks focus more on the process (how) rather than the system goals. On the other hand, the available egovernment RE framework, such as the one suggested by Tambouris et al., 2014 and Palkovits \& Wimmer, 2003, partially addresses the system goals but completely ignores the process (how). For example, the framework proposed by Palkovits \& Wimmer, 2003, suggests different models for modelling public services; however, it 
does not show how those models are developed. It also doesn't explore all e-government IS contexts such as integration and information.

GISREF has been designed to address most egovernment IS RE aspects, such as process, goals, and offerings. If properly applied, it has the potential to eliminate or minimize defects in the RE processes of e-government IS projects. The framework stimulates the thinking and imaginations of analysts and eventually helps them discover and elicit more and useful egovernment IS requirements. The framework first suggests breaking the e-government IS into twelve (12) viewpoints. By doing this, an analyst breaks the complex task into smaller and manageable tasks. The twelve (12) viewpoints were carefully identified to ensure that all requirements for particular e-government IS are elicited and specified accordingly.

In addition to that, GISREF introduces a concept of the core and value-adding services in RE of egovernment IS. Value-adding services correspond to supplementary services that can be offered by the government institution to take advantage of the new technology. These services could not be provided previously because of the lack of a mechanism to provide them. For example, the government health facility using the Health Facility Management Information System can send SMS reminders to parents to remind them about the next vaccination date for their new-borns. It is common among most government organisations to implement egovernment systems for only core services and thus failing to innovate new services to take advantage of the technology.

Heeks (2001) developed the design - reality gaps model centred around seven dimensions of Information, Technology, Process, Objective and values, Staffing and Skills, Management structures and systems, and Other resources, abbreviated as ITPOSMO. The gaps between the design and reality in these seven (7) dimensions must be minimized to ensure the successful implementation of the e-government IS project. Successful implementation of e-government IS in an organisation requires proper alignment of people, process, technology, and partners. The organisational viewpoint was introduced to capture organisational requirements to implement the new e-government IS. In this viewpoint, requirements for new organisation structure, staff, skills, collaborating partners, and processes are elicited and analysed while keeping the design-reality gap as minimal as possible. The goal is to identify organisational changes required to implement, use, and adopt a new system; and smoothly manage the transition from the old to the new structure and processes. For example, in the RER case study, for the system to function as anticipated, it required several changes in terms of organisational structures and staff job profiles. However, these changes were not documented as prerequisites requirements for establishing the systems.

Most e-government IS projects fail due to inadequate project management. Implementation of e-government projects should adopt and use proven project management methodologies and tools. To address this problem, EVM includes a project management viewpoint. In this viewpoint, the analyst should identify project management requirements for the successful development and implementation of e-government IS in question.

The e-government goals model (EGM) is a goal reference model that helps analysts elicit goals for different viewpoints. The model's generic goals should be translated into specific goals of the e-government IS project in question. For example, during the case study, nine strategic goals for the road safety information system were identified. The topmost goal was "To improve road safety." RER module was assigned to the goal "To improve emergency responses to road accidents." The use of goals in RE assists in triggering analysts' reasoning hence yielding more hidden requirements.

\section{Conclusion}

The benefits associated with the implementation and use of e-government IS does come for granted. E-government IS must be engineered to offer those benefits from the early stage of RE. Emerging technologies such as artificial intelligence (AI), cloud computing, quantum computing, and blockchain are expected to revolutionise the way governments work and deliver services. These technologies open up 
more government opportunities to develop and implement e-government IS, which are citizencentric, user-friendly, and offer personalised services. However, developing and implementing e-government systems to take advantage of these new technologies is even more complicated than today's e-government systems. Implementing such solutions will require a lot of work and effort to plan, analyze the requirements, design the data exchange, and coordinate mechanisms of various services offered by various government agencies. The proposed framework attempts to addresses two out of eight identified challenges of RE of egovernment IS. Therefore, future research should focus not only on testing and improving the

\section{References}

Abbas, A., Faiz, A., Fatima, A., \& Avdic, A. (2017). Reasons for the failure of government IT projects in Pakistan: A contemporary study. IEEE - 14th International Conference on Service Systems and Service Management (ICSSSM 2017). https://doi.org/10.1109/ICSSSM.2017.7 996223

Abrahão, S., Insfran, E., González-Ladrón-deGuevara, F., Fernández-Diego, M., CanoGenoves, C., \& Pereira de Oliveira, R. (2019). Assessing the effectiveness of goal-oriented modeling languages: A family of experiments. Information and Software Technology, 116 (2019) 106171. https://doi.org/10.1016/j.infsof.2019.08 .003

Abu-shanab, E. A. (2015). E-democracy: the fruit of e-government. International Journal of Technology and Globalisation, 8(1).

Afyonluoğlu, M., Aydin, A., Sevil, S. G., Yüksel, E., \& Güngör, M. K. (2014). An egovernment project management approach with e-transformation perspective. International Journal of EBusiness and EGovernment Studies, 6(1), 21-33.

http://www.sobiad.org/eJOURNALS/j ournal_IJEBEG/arhieves/2014_1/musta fa_afyonlu.pdf

Aikins, S. K. (2012). Managing e-government projects: concepts, issues, and best practices. In H. Probs (Ed.), (Issue October, proposed framework but also on attempting to address other remaining challenges.

The framework proposed in this study, if properly applied, has the potential to facilitate adequate requirement engineering of complex egovernment systems and eventually enable governments to benefit from the use of egovernment IS and information technology in general.

\section{Acknowledgments}

Google partially supported this work through Google Africa Ph.D. Fellowship program

pp. 42-60). Information Science Reference (an imprint of IGI Global). https://doi.org/10.4018/978-1-46660086-7.ch003

Al-khanjari, Z., Al-hosni, N., \& Kraiem, N. (2014). Developing a service oriented egovernment architecture towards achieving e-government interoperability. International Journal of Software Engineering and Its Applications, 8(5), 29-42. https://doi.org/http://dx.doi.org/10.1 4257/ijseia.2014.8.5.04

Anwer, S., Wen, L., \& Wang, Z. (2019). A systematic approach for identifying requirement change management challenges. Proceedings of the Evaluation and Assessment on Software Engineering, 230-235.

https://doi.org/10.1145/3319008.33190 31

Australia. National Office for the Information Economy. \& DMR Consulting. (2003). eGovernment Benefits Study. In NOIE.

Ayachi, R., Boukhris, I., Mellouli, S., Ben Amor, N., \& Elouedi, Z. (2016). Proactive and reactive e-government services recommendation. Universal Access in the Information Society, 15(4), 681-697. https://doi.org/10.1007/s10209-0150442-z

Baguma, R., \& Lubega, J. (2013). Factors for success and failure of e-government projects. Proceedings of the 7 th International Conference on Theory and Practice of Electronic Governance - ICEGOV 
'13,

194-197.

https://doi.org/10.1145/2591888.25919

21

Bakunzibake, P., Grönlund, Å., \& Klein, G. O. (2018). E-government implementation in developing countries: Enterprise Content Management in Rwanda. Electronic Government and Electronic Participation.

https://doi.org/10.3233/978-1-61499670-5-251

Boota, M. W., Ahmad, N., \& Masoom, A. H. (2014). Requirement engineering issues and their solutions. International Journal of Engineering and Technical Research (IJETR), 2(11), 50-56.

Botchkarev, A., \& Finnigan, P. (2015). Complexity in the context of information systems project management. Organisational Project Management, 2(1),15. https://doi.org/10.5130/opm.v2i1.4272

Brewer, G. A., Neubauer, B. J., \& Geiselhart, K. (2006). Designing and implementing egovernment systems. Administration $\mathcal{E}$ Society, 38(4), 472-499. https://doi.org/10.1177/0095399706290 638

Bubenko, J. A. (1995). Challenges in requirements engineering. Proceedings of 1995 IEEE International Symposium on Requirements Engineering (RE'95), 160-162. https://doi.org/10.1109/isre.1995.51255 7

Choi, T., \& Chandler, S. M. (2020). Knowledge vacuum: an organizational learning dynamic of how e-government innovations fail. Government Information Quarterly, 37(1), 101416. https://doi.org/10.1016/j.giq.2019.1014 16

Chutimaskul, W., Funilkul, S., \& Chongsuphajaisiddhi, V. (2008). The quality framework of e-government development. ICEGOV '08 Proceedings of the 2nd International Conference on Theory and Practice of Electronic Governance, 105109.

https:// doi.org/10.1145/1509096.15091 17

Cordella, A., \& Tempini, N. (2015). E-government and organizational change: Reappraising the role of ICT and bureaucracy in public service delivery. Government Information Quarterly, 32(3), 279-286. https://doi.org/10.1016/j.giq.2015.03.0 05

Dada, D. (2006). The failure of e-government in developing countries: a literature review. The Electronic Journal of Information Systems in Developing Countries, 26(1), 110. https://doi.org/10.1002/j.16814835.2006.tb00176.x

Dahiya, D., \& Mathew, S. K. (2018). IT infrastructure capability and egovernment system performance: an empirical study. Transforming Government: People, Process and Policy, 12(1), 16-38. https://doi.org/10.1108/TG-07-20170038

Damoah, I. S., \& Akwei, C. (2017). Government project failure in Ghana: a multidimensional approach. International Journal of Managing Projects in Business, 10(1), 32-59. https://doi.org/http://dx.doi.org/10.1 108/IJMPB-02-2016-0017

Damodaran, L., Nicholls, J., Henney, A., Land, F., \& Farbey, B. (2005). The contribution of sociotechnical systems thinking to the effective adoption of e-government and the enhancement of democracy. Electronic Journal of e-Government Volume 3 Issue 1 2005(1-12)

DeLone, W. H., \& McLean, E. R. (2003). The DeLone and McLean model of information system Success. Journal of Management Information Systems, 19(4), 930.

https://doi.org/10.1080/07421222.2003. 11045748

Elenezi, H., Tarhini, A., Masa'deh, R., Alalwan, A., \& Al-Qirim, N. (2017). Factors affecting the adoption of e-government in Kuwait: a qualitative study. Electronic Journal of E-Government, 15(2), 84-102.

Ghapanchi, A., \& Albadvi, A. (2008). A framework for e-government planning and implementation. Electronic Government, An International Journal, 5(1), 71-90.

https://doi.org/10.1504/EG.2008.01612 9 
Goedeke, J., Mueller, M., \& Pankratz, O. (2017). Uncovering the causes of information system project failure. Twenty-Third Americas Conference on Information Systems, Boston, 2017, 1-10.

Gunawong, P., \& Gao, P. (2017). Understanding e-government failure in the developing country context: a process-oriented study. Information Technology for Development, 23(1), 153-178. https://doi.org/10.1080/02681102.2016. 1269713

Gupta, K. P., Singh, S., \& Bhaskar, P. (2016). Citizen adoption of e-government: a literature review and conceptual framework. Electronic Government, an International Journal, 12(2), 160-185. https://doi.org/10.1504/eg.2016.076134

Hallowell, M., \& Gambatese, J. A. (2010). Qualitative research: application of the Delphi method to CEM Research. Qualitative Research. https://doi.org/10.1061/(ASCE)CO.194 3-7862.0000137

Hanna, N. K., Qiang, C. Z., Kaoru, K., \& Kuek, S. C. (2009). National e-government institutions: functions, models, and trends. In Information and Communications for Development 2009 (pp. 83-102).

Heeks, R. (2001). Understanding e-governance for development. Ifip, 11(3), 1-27.

Heeks, R. (2003). Most e-government for development projects fail: how can risks be reduced? IGovernment Working Paper Series, 14, 1-30. https://doi.org/10.1017/CBO978110741 5324.004

Hofmann, H. F., \& Lehner, F. (2001). Requirements engineering as a success factor in software projects. IEEE Software, 18(4).

https://doi.org/10.1109/MS.2001.93621 9

Hossan, C. G., Habib, W., \& Kushchu, I. (2006). Success and failure factors for egovernment projects implementation in developing countries: a study on the perception of government officials of Bangladesh.

Hussain, A., Mkpojiogu, E. O. C., \& Kamal, F. M. (2016). The role of requirements in the success or failure of software projects.
International Review of Management and Marketing, 6(S7), 306-311. http:/ / search.proquest.com/openview /273231aa4e14b0f8e73ea48b75997407/1 ?pq-origsite $=$ gscholar\&cbl $=816339$

Irani, Z., Al-sebie, M., \& Elliman, T. (2006). Transaction stage of e-government systems: identification of its location \& importance. 39th Hawaii International Conference on System Science, 1-9.

Jackson, E., Gunda, P., Kopoka, P. A., \& Kihonge, E. (2015). Role of e-government in delivery of public services in Tanzania Electric Supply Company in Ruvuma region, Tanzania. International Journal of Scientific \& Technology Research, 4(06). www.ijstr.org

Jacob, D. W., Md Fudzee, M. F., Salamat, M. A., Kasim, S., Mahdin, H., \& Ramli, A. A. (2017). Modelling end-user of electronicgovernment service: the role of information quality, system quality and trust. IOP Conference Series: Materials Science and Engineering, 226(1). https://doi.org/10.1088/1757899X/226/1/012096

Joseph, S., \& Avdic, A. (2016). Where do the Nordic Nations' strategies take egovernment? Electronic Journal of EGovernment, 14(1), 3-17.

Juell-Skielse, G., Lönn, C. M., \& Päivärinta, T. (2017). Modes of collaboration and expected benefits of inter-organizational e-government initiatives: a multi-case study. Government Information Quarterly, 34(4), 578-590. https://doi.org/10.1016/j.giq.2017.10.0 08

Kassen, M. (2015). Understanding systems of egovernment: e-federalism and ecentralism in the United States and Kazakhstan. In Lexington Books. Rowman $\mathcal{E} \quad$ Littlefield: Lexington Books. https://books.google.com/books?id=zL K6CgAAQBAJ\&pg=PA176\&dq=Maxat + Kassen\&hl=en\&sa $=X \& v e d=0 a h U K E w j 3$ 2f7kqOLYAhUJIcAKHbVABdAQ6AEIK $\mathrm{TAB}$

Kayed, A., Nizar, M., \& Alfayoumi, M. (2010). Ontology concepts for requirements engineering process in e-government applications. 5th International Conference 
on Internet and Web Applications and Services, ICIW 2010, 396-400. https://doi.org/10.1109/ICIW.2010.66

Komba, M. M., \& Ngulube, P. (2014). Factors that influence e-government adoption in selected districts of Tanzania. ESARBICA Journal, 33, 1-19. https://doi.org/10.1007/s13277-0154009-7

Lam, W. (2005). Barriers to e-government integration. Journal of Enterprise Information Management, 18(5), 511-530. https://doi.org/10.1108/1741039051062 3981

Lau, E. (2003). Challenges for e-government development. 5th Global Forum on Reinventing Government Mexico City, 5 November 2003:

Lufunyo, H. (2014). Impact of public sector reforms on service delivery in Tanzania. Journal of Public Administration and Policy Research, 5(2), 26-49. https://doi.org/10.5897/jpapr12.014

Mansor, Z., \& Enebeli, N. (2015). Issues, challenges and best practices of software testing activity. Proceedings of the 14th International Conference on Applications of Computer Engineering (ACE' 15), Seoul, South Korea, 42-47.

Martin, R. L., \& Montagna, J. M. (2006). Business process reengineering role in electronic government. The Past and Future of Information Systems: 1976-2006 and Beyond. IFIP WCC TC8 2006. IFIP International Federation for Information Processing, Vol 214. Springer, Boston, MA, 0-12. https://doi.org/10.1007/978-0387-34732-5

Mawela, T., Ochara, N. M., \& Twinomurinzi, H. (2017). E-government implementation: a reflection on South African Municipalities. South African Computer Journal, 29(1), 147-171. https://doi.org/10.18489/sacj.v29i1.444

Michael, K. A., \& Boniface, K. A. (2014). Inadequate requirements engineering process: A key factor for poor software development in developing nations: a case study. International Journal of Computer, Electrical, Automation, Control and Information Engineering Vol:8, 8(9), 1572-1575.
Mkude, C. G., \& Wimmer, M. A. (2013). Strategic framework for designing e-government in developing countries. Egov 2013, 148162.

http://link.springer.com/chapter/10.10 07/978-3-642-40358-3_13

Mpinganjira, M. (2015). Use of e-government services: the role of trust. International Journal of Emerging Markets, 10(4), 622633. https://doi.org/10.1108/IJoEM-122013-0151

Mukamurenzi, S., Grönlund, Å., \& Islam, M. S. (2019). Challenges in implementing citizen-centric e-government services in Rwanda. Electronic Government, an International Journal, 15(3), 283. https://doi.org/10.1504/EG.2019.10051 9

Mukherjee, I. (2008). Understanding information system failures from the complexity perspective. Journal of Social Sciences, 4(4), 308-319. https://doi.org/10.3844/jssp.2008.308.3 19

Mullery, G. P. (1979). CORE - a method for controlled requirement specification. Proceedings of the 4th International Conference on Software Engineering, 126135.

http:/ / dl.acm.org/citation.cfm?id=8000 91.802932

Ndou, V. D. (2004). E - government for developing countries: opportunities and challenges. The Electronic Journal of Information Systems in Developing Countries, 18(1), 1-24. https://doi.org/10.1002/j.16814835.2004.tb00117.x

Nograsek, J. (2011). Change management as a critical success factor in e-government implementation. Business Systems Research, 2(2), 1-56.

Ojha, S., \& Pandey, I. M. (2017). Management and financing of e-government projects in India: does financing strategy add value? IIMB Management Review, 20, 119. https://doi.org/10.1016/j.iimb.2017.04. 002

Oliveira, A. D. A., \& Eler, M. M. (2017). Strategies and challenges on the accessibility and interoperability of e-government web 
portals: A case study on Brazilian Federal Universities. Proceedings International Computer Software and Applications Conference, 1, 737-742. https://doi.org/10.1109/COMPSAC.20 17.222

Otieno, I., \& Omwenga, E. (2015). Citizen-centric critical success factors for the implementation of e-government: a case study of Kenya huduma centres. 2015 IST-Africa Conference, 1-9. https:// doi.org/10.1109/ISTAFRICA.20 15.7190525

Owusu-Ansah, S. (2014). Human factor issues in the use of E-government services among Ghanaian middle age $p$ : improving usability of existing and future government virtual interactive systems design. Journal of Information Engineering and Applications, 4(4), 85-107.

Palkovits, S., \& Wimmer, M. A. (2003). Processes in e-government - A holistic framework for modelling electronic public services. EGOV 2003, 213-219. https://doi.org/10.1007/10929179_39

Pandey, D., Suman, U., \& Ramani, A. K. (2010). An effective requirement engineering process model for software development and requirements management. Proceedings - 2nd International Conference on Advances in Recent Technologies in Communication and Computing, ARTCom 2010, 287-291. https://doi.org/10.1109/ARTCom.2010 .24

Paulin, A. (2015). Twenty years after the hype: Is e-government doomed? Findings from Slovenia Alois. International Journal of Public Administration in the Digital Age, 2(2), 1-21. https://doi.org/10.4018/ijpada.2015040 101

Putra, D. A. D., Jasmi, K. A., Basiron, B., Huda, M., \& Maseleno, A. (2018). Tactical steps for e-government development. 119(15), 2251-2258.

Rahman, S., Rashid, N., \& Yadlapalli, A. (2014). Determining factors of e-government implementation: A multi-criteria decision - making. Pacific Asia Conference on Information Systems.
Rajala, T., \& Aaltonen, H. (2020). Reasons for the failure of information technology projects in the public sector. The Palgrave Handbook of the Public Servant, 1-19. https://doi.org/10.1007/978-3-03003008-7_78-1

Rajapakse, J., Van Der Vyver, A., \& Hommes, E. (2012). e-government implementations in developing countries: success and failure, two case studies. 2012 IEEE 6th International Conference on Information and Automation for Sustainability, 95-100. https://doi.org/10.1109/ICIAFS.2012.6 419888

Rana, N. P., Dwivedi, Y. K., \& Williams, M. D. (2015). A meta-analysis of existing research on citizen adoption of egovernment. Information Systems Frontiers, 17(3), 547-563. https://doi.org/10.1007/s10796-0139431-z

Reffat, R. (2003). Developing a successful egovernment. The Proceedings of the Symposium on E-Government: Opportunities and Challenge, Muscat Municipality, IV1-IV13. http://faculty.kfupm.edu.sa/ARCH/ra bee/publications_files/03Reffat_eGov.p df

Sánchez-Torres, J. M., \& Miles, I. (2017). The role of future-oriented technology analysis in e-government: a systematic review. European Journal of Futures Research, 5(1). https://doi.org/10.1007/s40309-0170131-7

Shah, S. R. A., Khan, A. Z., \& Khalil, D. M. S. (2011). Project management practices in e-government projects: a case study of electronic government directorate (EGD) in Pakistan. International Journal of Business and Social Science, 2(7). http://citeseerx.ist.psu.edu/viewdoc/d ownload?doi=10.1.1.463.2413\&rep=rep1 \&type $=\mathrm{pdf}$

Shah, T., \& Patel, S. V. (2014). A review of requirement engineering lisues and challenges in various software development methods. International Journal of Computer Applications, 99(15), 975-8887.

https://doi.org/10.5120/17451-8370 
Shrivastava, D. R. K., Raizada, D. A. K., \& Saxena, M. N. (2014). Role of e-governance to strengthen higher education system in India. IOSR Journal of Research $\mathcal{E}$ Method in Education (IOSRJRME), 4(2), 57-62. https://doi.org/10.9790/7388-04215762

Simonofski, A., Ayed, H., Vanderose, B., \& Snoeck, M. (2018). From traditional to agile e-government service development: starting from practitioners' challenges. Americas Conference on Information Systems 2018: Digital Disruption, AMCIS 2018, 1-10.

Sorn-in, K., Tuamsuk, K., \& Chaopanon, W. (2015). Factors affecting the development of e-government using a citizen-centric approach. Journal of Science and Technology Policy Management, 6(3), 206222. https://doi.org/10.1108/JSTPM05-2014-0027

Stefanovic, D., Marjanovic, U., Delić, M., Culibrk, D., \& Lalic, B. (2016). Assessing the success of e-government systems: an employee perspective. Information and Management, 53(6), 717-726. https:// doi.org/10.1016/j.im.2016.02.00 7

Stephen, A. O., Ayodotun, I., Iyoha, F. ., Charles, K. A., \& Daniel, G. (2017). The role of egovernment in Nigeria's tax system: strategy perspective to enhance complience. The Social Sciences, 12(8), 1482-1486.

Sun, P. L., Ku, C. Y., \& Shih, D. H. (2015). An implementation framework for eGovernment 2.0. Telematics and Informatics, 32(3), 504-520. https://doi.org/10.1016/j.tele.2014.12.0 03

United Nations. (2018). United Nations EGovernment Survey 2018.

United Nations. (2020). 2020 UN e-government survey.

https://publicadministration.un.org/eg ovkb/en-us/Reports/UN-E-

Government-Survey-2020

Van Der Waldt, G., (2002). E-governance: where do we stand and what are the challenges? Administratio Publica, 11(2), 1-14.

van Velsen, L., van der Geest, T., ter Hedde, M., \& Derks, W. (2009). Requirements
Swartz, E. M. J. (2018). Challenges to the implementation of business process reengineering of the eecruitment process in the ministry of fisheries and marine resources, Namibia.

Sweis, R. J. (2015). An investigation of failure in information systems projects: The case of Jordan. Journal of Management Research, 7(1), 173-185. https://doi.org/10.5296/jmr.v7i1.7002

Tambouris, E., Kaliva, E., \& Liaros, M. (2014). A reference requirements set for public service provision enterprise architectures. 991-1013. https://doi.org/10.1007/s10270-0120303-7

Toots, M. (2019). Why e-participation systems fail: The case of Estonia's Osale.ee. Government Information Quarterly, February, $\quad 0-1$. https://doi.org/10.1016/j.giq.2019.02.0 02

Trkman, P. (2010). The critical success factors of business process management. International Journal of Information Management, 30, 125-134. https://doi.org/10.1016/j.ijinfomgt.200 9.07.003

Twizeyimana, J. D., Larsson, H., \& Grönlund, ^̊. (2018). E - government in Rwanda: Implementation, challenges and reflections. The Electronic Journal of EGovernment, 16(1), 19-31.

United Nations. (2016). United Nations egovernment survey 2016. http://workspace.unpan.org/sites/Inte rnet/Documents/UNPAN97453.pdf https://doi.org/10.1016/j.giq.2009.02.0

07

engineering for e-Government services: A citizen-centric approach and case study. Government Information Quarterly, 26(3), 477-486.

Vrakas, N., Kalloniatis, C., Tsohou, A., \& Lambrinoudakis, C. (2010). Privacy requirements engineering for trustworthy e-government services. Lecture Notes in Computer Science (Including Subseries Lecture Notes in Artificial Intelligence and Lecture Notes in Bioinformatics), 6101 LNCS, 298-307. 
https:/ / doi.org/10.1007/978-3-64213869-0_22

Vyas, V., Vyas, S., \& Kundan, A. (2014). Management information system: information needs of organization. International Journal of Information $\mathcal{E}$ Computation Technology, 4(17), 1903-1908.

Zakaria, M. R., \& Gebba, T. R. (2014). Towards categorizing e-government services: The case of Egypt. International Journal of
Business Research, 3(3), 16-28. www.sciencetarget.com

Zakaria, N. H., Haron, A., Sahibuddin, S., \& Harun, M. (2011). Requirement engineering critical issues in public sector software project success factor. International Journal of Information and Electronics Engineering, 1(3). http://www.ijiee.org/papers/32I038.pdf 